Zeszyty Naukowe Szkoły Głównej Gospodarstwa Wiejskiego w Warszawie

Problemy Rolnictwa Światowego tom 18 (XXXIII), zeszyt 2, 2018: 259-269

DOI: $10.22630 /$ PRS.2018.18.2.53

Anna Sieczko $^{1}$, Leszek Sieczko ${ }^{2}$

Szkoła Główna Gospodarstwa Wiejskiego w Warszawie

\title{
Determinanty popytu usług agroturystycznych
}

\section{Determinants of Demand for Agritourism Services}

\begin{abstract}
Synopsis. W artykule podjęto próbę określenia głównych determinant usług agroturystycznych wśród turystów z Polski oraz Ukrainy i Białorusi. W ostatnim czasie grupa imigrantów zarobkowych z Ukrainy gwałtownie wzrosła i zaczęto zauważać ich nie tylko jako pracowników ale także konsumentów. Celem pracy było określenie głównych determinant wpływających na postrzeganie agroturystyki. Badania zostały przeprowadzone w formie kwestionariusza ankiety. Przedstawione wyniki opierają się na 250 respondentach. Wskazane zostały główne cechy brane pod uwage podczas wyboru usług agroturystycznych. Badane cechy są przedstawione w czterostopniowej skali co pozwala w szczegółach dokładniej podzielić turystów usług agroturystycznych.
\end{abstract}

Słowa kluczowe: gospodarstwa agroturystyczne, baza noclegowa, atrakcje turystyczne, wyżywienie w gospodarstwach.

\begin{abstract}
The article attempts to determine the main determinants of agritourism services among tourists from Poland, Ukraine and Belarus. Recently, the number of labor immigrants from Ukraine has grown sharply and they are being noticed not only as employees but also as consumers. The purpose of the work was to determine the main determinants affecting the perception of agritourism. The research was carried out in the form of a questionnaire. The results presented are based on 250 respondents. The main features taken into consideration during the selection of agrotourism services were indicated. The examined features are presented in a four-level scale, which allows to more precisely divide users of agritourism services.
\end{abstract}

Key words: agritourism farms, accommodation, tourist attractions, food on farms.

JEL Classification: L83, D12, Z39

\section{Wstęp}

Funkcjonowanie rynku usług agroturystycznych jest związane $\mathrm{z}$ występowaniem podmiotów rynku czyli nabywców (turystów) po stronie popytu oraz sprzedawców (właścicieli gospodarstw agroturystycznych) reprezentujących podaż. Muszą też istnieć dobra i usługi, które można miedzy sobą wymieniać po ustalonej cenie i określone w prawie przepisy takiej wymiany. Agroturystyka w Polsce nie jest działalnościa gospodarczą. W myśl ustawy z dnia 2 lipca 2004 (Dz. U. Nr. 173, 2004), prowadzenie działalności agroturystycznej umożliwiono wyłącznie rolnikom. Nie muszą zakładać działalności gospodarczej i zgłaszać jej do ewidencji gospodarczej (Dudzińska-Krawczyk, 2016). W literaturze przedmiotu pojęcie agroturystyki jest różnorodnie przedstawiane.

\footnotetext{
${ }^{1}$ dr, Katedra Ekonomiki Edukacji, Komunikowania i Doradztwa SGGW w Warszawie, ul. Nowoursynowska 166, 02-787 Warszawa, e-mail: anna_sieczko@sggw.pl; https://orcid.org/0000-0001-9065-0362

${ }^{2} \mathrm{dr}$, Katedra Doświadczalnictwa i Bioinformatyki SGGW w Warszawie, ul. Nowoursynowska 159, 02-776 Warszawa, e-mail: leszek_sieczko@sggw.pl
} 
Dla potrzeb niniejszej pracy przyjęto definicję za Sikorą (2012), który określa ją jako specyficzny rodzaj turystyki wiejskiej (alternatywnej) organizowany przez rodziny rolnicze z wykorzystaniem mieszkaniowo-wczasowych zasobów gospodarstwa rolnego oraz zasobów przyrodniczych, kulturalnych i infrastrukturalnych wsi i regionu. Dla rolników jest ona traktowana jako możliwość wykorzystania zasobów, którymi dysponują (pokoje, przestrzeń wokół gospodarstwa domowego, zwierzęta gospodarskie, rośliny uprawne itp.) w celach zarobkowych. Dla turystów umożliwia nie tylko odpoczynek na terenach wiejskich ale także edukację związaną z szeroko pojmowanym wiejskim gospodarstwem domowym i gospodarstwem rolnym, poznanie kultury regionu, jego historii, folkloru, zwyczajów i tradycji oraz uprawiania szeroko pojmowanej aktywności fizycznej zarówno na działce siedliskowej, ale także bliższej i dalszej przestrzeni wiejskiej.

Na popyt agroturystyczny ma wpływ wiele czynników o różnym charakterze. Należą do nich czynniki: ekonomiczne, demograficzne, postawy społeczno-kulturowe i społeczne, mobilność, regulacje prawne oraz podaż. Współcześnie zmieniają się one bardzo szybko, co wymaga stałej uwagi i śledzenia tendencji na rynku. Rosnące znaczenie usług agroturystycznych zarówno dla polskiej wsi jak i turystów, wymusza przeprowadzenia badań obejmujących czynniki i strukturę popytu usług agroturystycznych zarówno wśród polskich i zagranicznych turystów. Celem badania było poznanie istotnych czynników determinujących wybór usługi agroturystycznej, zarówno wśród polskich, jak i zagranicznych konsumentów.

\section{Materiał i metody}

Badanie przeprowadzono w formie kwestionariusza ankiety w okresie kwiecień - maj 2017 roku. W badaniu wzięło udział 250 osób, w tym 20 osób z poza Polski (Ukraina, Białoruś). Reprezentacja w grupie badanej obcokrajowców wynosząca $8 \%$ próby była zbliżona do proporcji $\mathrm{w}$ narodowości zatrudnionych $\mathrm{w}$ Polsce $\mathrm{w}$ połowie 2017 roku. Kwestionariusz składał się z trzech części: metryczki, pytań dotyczących wyjazdów agroturystycznych w 2016 roku oraz oceny ważności determinant popytu wśród badanych osób. Metryczka zawierała pytania o: płeć, wiek, wykształcenie, zawód wykonywany, miejsce zamieszkania, miesięczne dochody brutto na jedną osobę oraz kraj stałego zamieszkania.

Determinanty, których było 71 zostały podzielone na osiem pytań w których można było wskazać odpowiedzi wraz z czterostopniową oceną ich ważności dla respondenta. Warianty oceny to „bardzo ważny”, „ważny”, „mało ważny” i „nieważny”. Tym ocenom jakościowym przypisano wartości liczbowe (liczby od 1 do 4) w celu poszerzenia możliwości zastosowania metod statystycznych do oceny. Tak przyjęta transformacja miar będzie miała odmienną interpretację przy współczynniku korelacji. Dodatnie współczynniki oznaczać będą spadek ważności determinanty a ujemne jej wzrost.

W pracy wykonano analizy statystyczne takie jak szeregi rozdzielcze, prezentacje graficzną, wyznaczono współczynnik korelacji Pearsona. Analizy wykonano w arkuszu kalkulacyjnym MS Excel oraz pakiecie statystycznym IBM SPSS Statistics wersja 24. 


\section{Istota popytu agroturystycznego}

W teorii ekonomii najogólniej popyt można zdefiniować jako ilość dobra, jaką kupujący są w stanie nabyć w określonym czasie i po określonej cenie. Definicja popytu agroturystycznego nie odbiega od ogólnej definicji popytu. Według Wodejko popyt turystyczny jest to zapotrzebowanie na produkt turystyczny przy określonej cenie i w danym okresie (Wodejko, 1997). Zatem pojęcie popytu agroturystycznego odnosi się do sytuacji, w której chęć nabycia produktów agroturystycznych występuje po określonym poziomie cen i w określonym czasie. Czynnikiem kształtującym popyt agroturystyczny sa potrzeby potencjalnych turystów, $\mathrm{z}$ drugiej zaś możliwości ich zaspokojenia, wyrażana jak już wspomniano zarówno poprzez ich siłę nabywczą ale także podaż na rynku usług agroturystycznych. Warto zwrócić uwagę na fakt, iż usługi agroturystyczne są oferowane przez rolników i traktowane jako dodatkowe źródło utrzymania, zatem nie zawsze struktura podaży agroturystycznej jest adekwatna do potrzeb turystów. Według Dziedzic i Skalskiej (2012) popyt turystyczny jest bardzo zróżnicowany. Na rynku występuje nie jakaś jedna określona ilość popytu na jednorodne dobro (usługę), ale raczej kompozycja, zbioru popytu na różne produkty wzajemnie wobec siebie komplementarne i/lub substytucyjne, determinowane przez ich ceny. Zjawisko to z ekonomicznego punktu widzenia utrudnia (a często nawet fałszuje) analizę czynników oddziałujących na rozmiar popytu z uwagi na to, że zakup poszczególnych usług (dóbr) cząstkowych może podlegać oddziaływaniu innych czynników, często wzajemnie wobec siebie sprzecznych, o przeciwstawnym kierunku działania. Popyt agroturystyczny ściśle wiąże się z produktem agroturystycznym. Według Zawadki (2010) do specyficznych składników produktu agroturystycznego odróżniających go od innych produktów turystycznych zaliczyć należy: noclegi (najczęściej w domu gospodarza), smaczne i zdrowe wyżywienie, wytwarzane niejednokrotnie z produktów pochodzących $\mathrm{z}$ własnego gospodarstwa, nieograniczona przestrzeń przyrodnicza, rekreacyjna, usługi przewodnickie (konno, traktorem, pieszo i inne), wypożyczanie sprzętu sportowo-rekreacyjnego, możliwość korzystania z sadu i ogrodu, kontakt ze zwierzętami gospodarskimi (nie tylko jazda konna, ale również karmienie i czyszczenie koni, podbieranie jaj kurzych, dojenie krowy itp.), nauka rzemiosła ludowego (możliwość samodzielnego wyplecenia koszyka, utkania kilimu, który jest namacalną pamiątką z pobytu w gospodarstwie), możliwość robienia przetworów domowych z owoców i warzyw, zbieranie i przetwarzanie owoców runa leśnego, uczestnictwo w pracach polowych, możliwość obserwacji unikalnych gatunków roślin i zwierząt (w przypadku obszarów chronionych lub w pobliżu rezerwatów).

Analizując produkt agroturystyczny można zauważyć, iż składa się on zarówno z dóbr, usług, jak i pozostałych elementów ściśle związanych z gospodarstwem rolnym, co powoduje, że może być szczególnie atrakcyjny dla turystów ze względu na odmienność w stosunku do życia w mieście (Żelazna i Woźniczko, 2005). Jednak popyt na konkretny produkt agroturystyczny wśród turystów jest bardzo subiektywny, dlatego też zarówno o jego wielkości jak i strukturze decydują czynniki niewymierne. Analiza literatury potwierdza, że popyt na produkty agroturystyczne ma charakter substytucyjny. Najczęściej przyczyny substytucji w turystyce ogółem są braki i zmiany w podaży zmiany cen, zmiany dochodów w gospodarstwach domowych. Może też być wynikiem preferencji, dążenia do maksymalnego zaspokojenia potrzeb w ramach dysponowania dochodów (Żelazna i Woźniczko, 2005). Popyt ma też charakter komplementarny ponieważ łączy w jeden produkt agroturystyczny popyt na wiele elementów podaży (nocleg, wyżywienie, rozrywkę, 
naukę, aktywność fizyczną). Ma też charakter restytucyjny (odnawialny) (Balińska i in., 2014), sezonowy, występuje również w grupie wydatków na swobodną konsumpcję, jest elastyczny cenowo i dochodowo (Gaworecki, 2003). Badanie popytu w agroturystyce jak wskazują badania naukowe są nie tylko istotne ale ważna jest również ich ocena ekonometryczna (Santeramo, Barbieri, 2017).

Jak zauważyła Balińska (2009) niezwykle ważne jest też ciagłe monitorowanie oczekiwań klientów i mierzenie poziomu ich satysfakcji. Walka o klienta za pomocą ceny w dłuższej perspektywie okazuje się nierentowna. Dotychczasowa praktyka pokazuje, że bardziej skutecznym atutem jest wysoka jakość. Zatem o popycie agroturystycznym decyduje wiele czynników, można stwierdzić, że jest kategorią rynkową wrażliwą na zmiany różnej natury.

\section{Wyniki badań}

Większość tj. 230 badanych pochodziła z Polski, 11 z Ukrainy i 9 z Białorusi. W sumie osoby z poza Polski stanowiły grupę $8 \%$ badanych. Średni ważony wiek respondentów wyniósł 35 lat. Najliczniejszą grupę $(38,4 \%)$ stanowiły osoby w wieku $18-25$ lat, kolejna grupa $(21,6 \%)$ to osoby w wieku 26-35 lat. Udział pozostałych respondentów $\mathrm{w}$ podziale na grupy wiekowe to: $11,2 \% \mathrm{w}$ grupie $36-45$ lat, $12,8 \% \mathrm{w}$ grupie $46-55$ lat, 7,6\% w grupie 56-70 lat, 4,4\% w grupie powyżej 70 lat oraz 4\% w grupie poniżej 18 lat.

Respondenci pod względem wykształcenia w większości posiadali wyższe wykształcenie $(53,6 \%)$, średnie - 32,8\%, zawodowe - $8,8 \%$ oraz podstawowe $-4,8 \%$. Pod względem zatrudnienia największą $(37,2 \%)$ grupą badanych były osoby pracujące na etacie, 34,4\% stanowili studenci i uczniowie, 12,8\% przedsiębiorcy, 7,6\% emeryci i renciści, 4,8 przedstawiciele wolnych zawodów oraz 3,2\% bezrobotni.

Deklarowany miesięczny dochód brutto na jedną osobę miał rozkład prawoskośny. Najwięcej osób zadeklarowało zarobki w przedziałach 1000-1500 zł (22,0\%) i 1500-2000 $(21,2 \%)$ oraz 2000-2500 (14,4\%). Kolejny przedział dochodu 2500-3000 wskazało 12,0\% badanych, 3000-4000 zaznaczyło 8,4\% osób. Dochód powyżej 4000 zł na osobę zadeklarowało $11,2 \%$ a poniżej $1000 \mathrm{zł}$ dochodu wskazało $10,8 \%$ badanych.

Miejsce zamieszkana, a czynniki wpływające na postrzeganie agroturystyki są ważne co najmniej $\mathrm{w}$ grupie osób zamieszkujących miasta. 39,2\% osób zamieszkiwało miasta o wielkości zaludnienia powyżej 200 tys. mieszkańców, 19,2\% miasta o wielkości od 50 tys. do 200 tys., 18,4\% miasta od 5 tys. do 50 tys. W sumie w największych miastach mieszkało 76,8\% wszystkich badanych. Ponad $17,2 \%$ mieszkało na wsi a w miastach poniżej 5 tys. mieszkańców tylko $6 \%$ badanych.

Z powodów technicznych objętości niniejszego opracowania i wielowątkowości badanych aspektów w dalszej części pracy zostaną przedstawione te czynniki, które zostały wskazane jako bardzo ważne i ważne w znacznej większości odpowiedzi.

Wybór gospodarstw agroturystycznego do którego chciałyby wybrać się osoby uczestniczące w badaniu został przedstawiony za pomocą dziesięciu najważniejszych czynników wybranych przez autorów. Osoby wypełniające ankietę oceniały w swoim odczuciu ważność, którą by się kierowały. Najwyżej ocenionym czynnikiem wyboru były interesujące atrakcje w okolicy - 93,4\% badanych wskazało odpowiedź „bardzo ważne” lub „ważne”. Jednakże w odpowiedziach jest kilka innych nieznacznie niżej ocenionych determinant, są to: położenie gospodarstwa agroturystycznego $-89,7 \%$, cena $-86,2 \%$, 
standard pokoi - 85,7\%, galeria zdjęć obiektu - 81,3\%, opinie gości - 79,8\%. Pozostałe czynniki wyboru ocenione były też dość wysoko, gdzie najniższą ocenę wyznaczono dla zamieszczenia filmów obiektu i atrakcji, wysoką ocenę wskazało 46,5\% badanych. Rozkłady ważności oceny poszczególnych motywów wyboru gospodarstwa przedstawiono na rysunku 1.

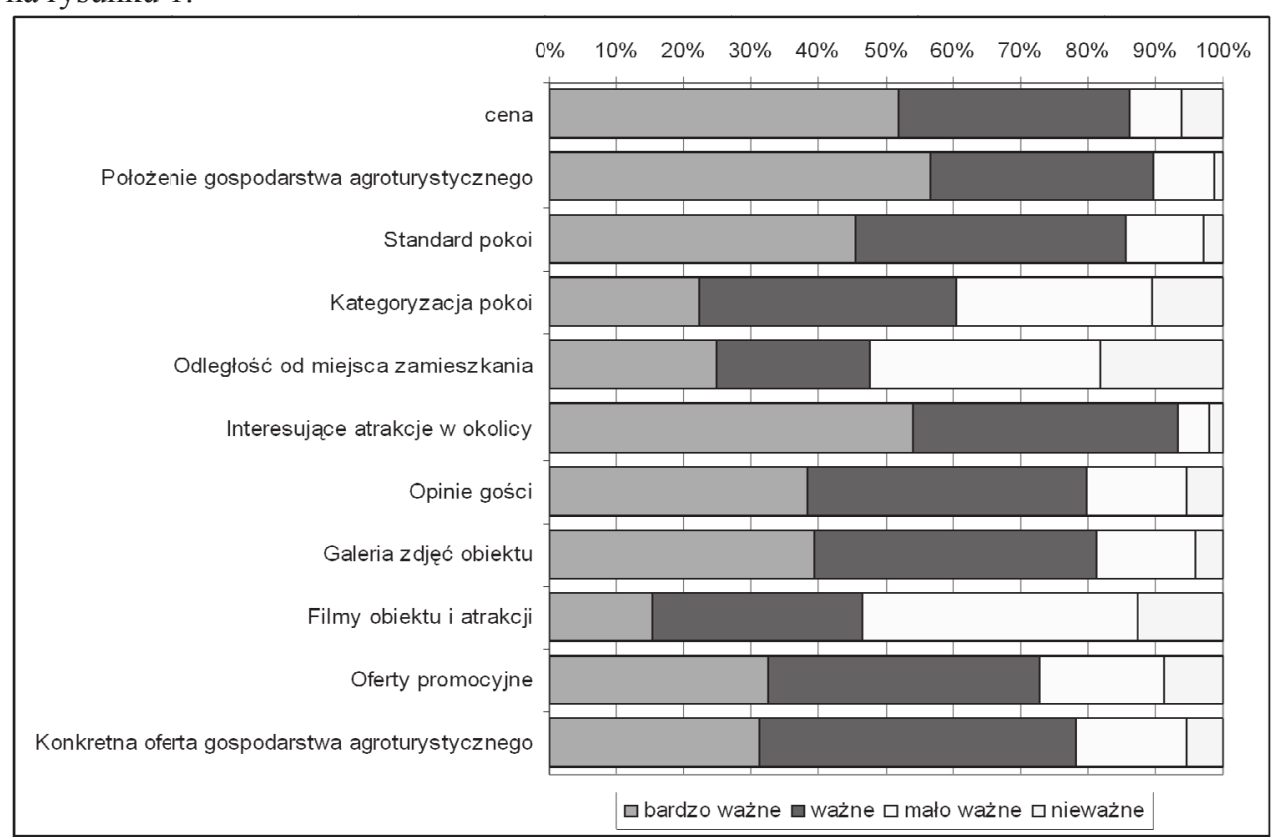

Rys. 1. Determinanty oraz ich ocena wyboru gospodarstwa agroturystycznego

Fig. 1. Determinants and their assessment of the selection of an agritourism farm

Źródło: opracowanie własne.

Przeciw wagą pozytywnych czynników skłaniających do wyboru gospodarstwa agroturystycznego są demotywatory, które mogą zaważyć nad podjętą decyzją. W pewnej części takimi czynnikami mogą być skrajne oceny czynników pozytywnych lecz czasami są one wymieniane przez turystów w sposób niezależny. Poddano ocenie dziesięć takich demotywatorów prosząc o wyrażenie ważności w skali jakościowej jak przy poprzednich czynnikach. Najbardziej zniechęcającym czynnikiem wyboru według respondentów byli niemili gospodarze, odpowiedź tę wskazało 93,9\%. Kolejnymi ważnymi demotywatorami były: brak łazienki w pokoju - 89,4, niski standard kwatery - 89,0\%, mało atrakcji w okolicy $-88,1 \%$, nuda $-84,5 \%$ oraz wysokie koszty wypoczynku $-84,4 \%$. Inne czynniki negatywnie wpływające na wybór gospodarstwa też zostały dość wysoko ocenione jako bardzo ważne i ważne (rys. 2). 


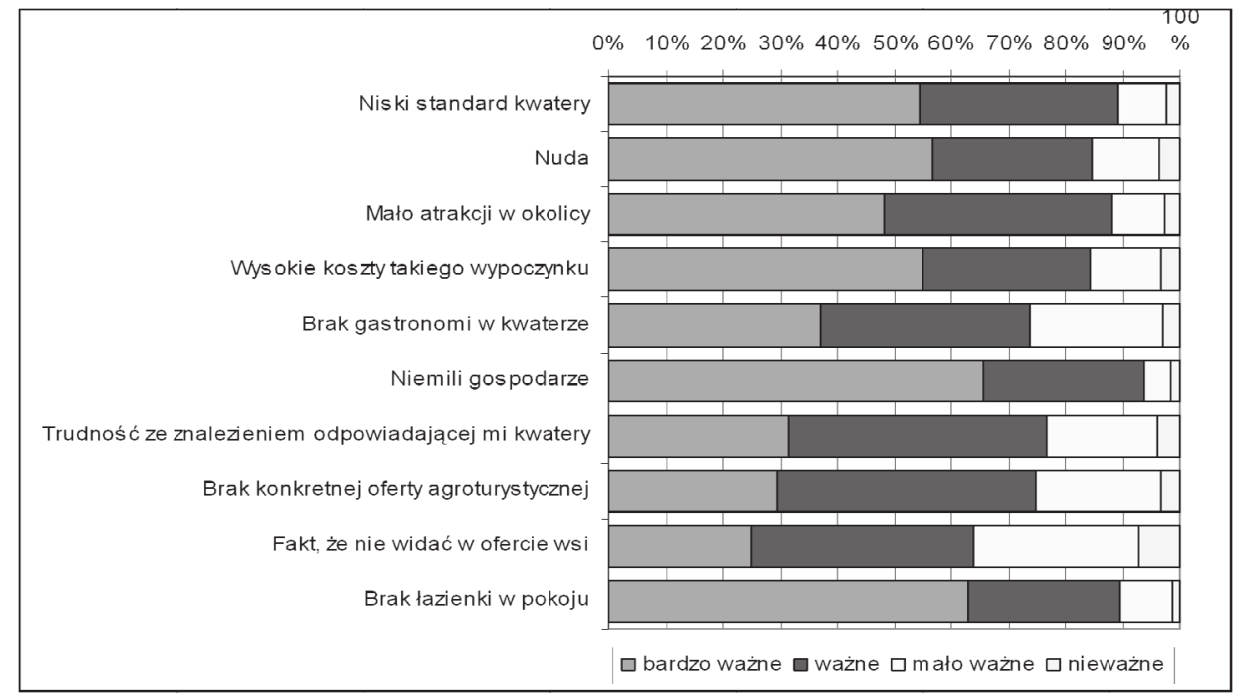

Rys. 2. Demotywatory oraz ich ocena wyboru gospodarstwa agroturystycznego

Fig. 2. Demotivators and their assessment of the selection of an agritourism farm

Źródło: opracowanie własne.

Kolejną grupą czynników stymulujących wybór gospodarstwa agroturystycznego jest ocena ważności samej bazy noclegowe i jej składowych. Najważniejszym czynnikiem branym pod uwagę przez badane osoby była czystość - 96,7\%, wygodne łóżko - 94,3\% oraz łazienka w pokoju - 91\%. Wraz ze zmieniającymi się pokoleniami zmieniają się też preferencje mediów elektronicznych wykorzystywanych do rozrywki. Dostęp do Internetu (zaznaczając odpowiedź - bardzo ważny i ważny) wskazało 60,7\% a wyposażenie kwatery w telewizor tylko 33,6\%. Pozostałe determinanty oraz ich rozkłady obrazuje rysunek 3.

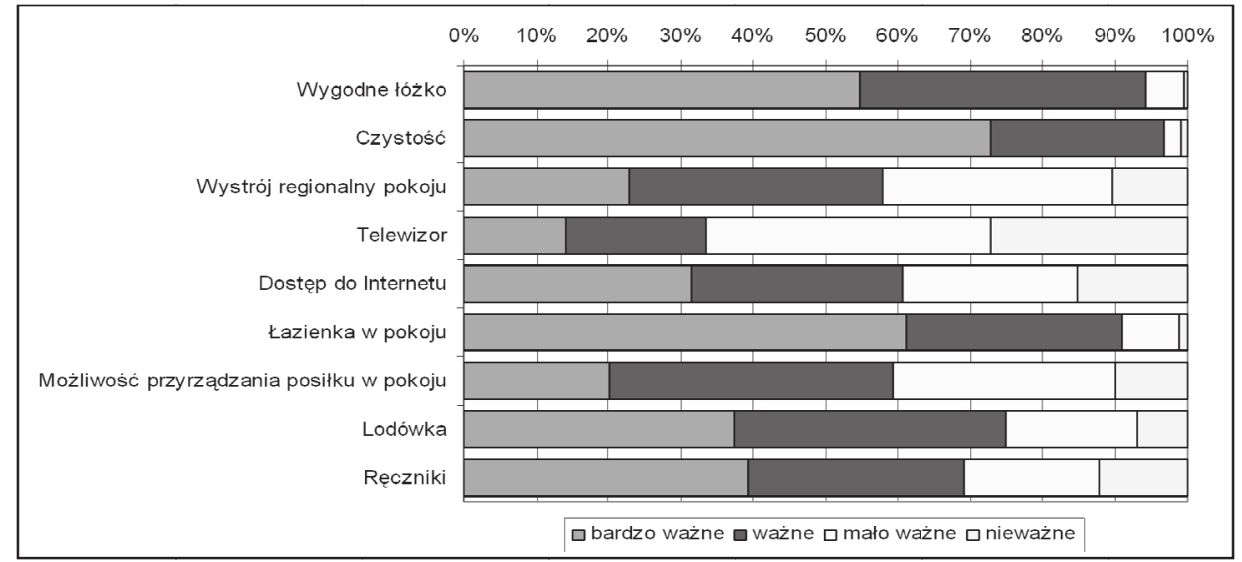

Rys. 3. Determinanty oraz ich ocena wyboru bazy noclegowej gospodarstwa agroturystycznego

Fig. 3. Determinants and their assessment of the selection of accommodation base for an agritourism farm Źródło: opracowanie własne. 
Kwatera agroturystyczna to nie tylko baza noclegowa, wiąże się z nią jeszcze wiele innych miejsc i obiektów towarzyszących, które mogą mieć duży wpływ na wybór. Ocenie respondentów zostało przedstawionych trzynaście determinant z tego zakresu. Najwyżej oceniona została atmosfera panująca w gospodarstwie $(93,4 \%$ oceniło jako bardzo ważną i ważną). Istotną determinantą dla ponad $91 \%$ respondentów było bezpieczeństwo turystów, następnie sposób obsługi $(87,8 \%$ ), standard kwatery $-86,1 \%$ oraz wyżywienie $84,6 \%$. Możliwość poznania lokalnej kultury wskazało blisko $3 / 4$ osób a poznanie pracy na wsi niespełna $1 / 2$ badanych. Należy podkreślić iż przedstawione determinanty na rysunku 4 są po części bardzo specyficzne, więc tym samym nie są pożądane przez znaczną większość turystów.

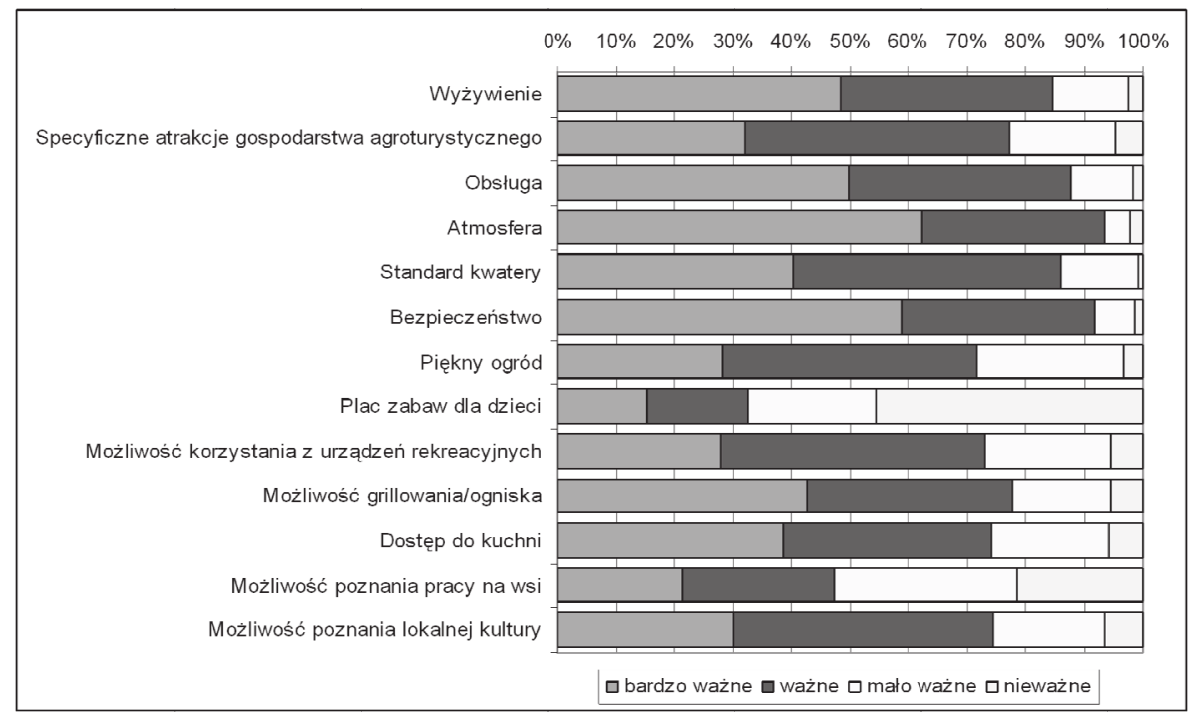

Rys. 4. Determinanty oraz ich ocena dotyczące samej kwatery agroturystycznej

Fig. 4. Determinants and their assessment regarding the agritourism lodging itself

Źródło: opracowanie własne.

Każdy pobyt turystyczny wiąże się z korzystania z bazy gastronomicznej. W części gospodarstw agroturystycznych nie jest oferowane wyżywienie ale może być w ofercie dostęp do kuchni lub świeżych produktów produkowanych na miejscu. Ponad $87 \%$ badanych uważa za bardzo ważne i ważne znalezienie w ofercie żywieniowej dań regionalnych lub dań kuchni domowej (86,4\%). 80,2\% respondentów wybierałoby oferty, gdzie jest możliwe całodzienne wyżywienie oparte na produktach pochodzących z gospodarstwa rolnika lub jego sąsiadów. Problemy oraz mody żywieniowe występujące w społeczeństwie coraz szerzej skłaniają do poszukiwania ofert które będą dawały możliwość realizowania specjalnej diety w gospodarstwach agroturystycznych. Blisko 72\% ankietowanych zainteresowanych jest żywnością ekologiczną a 64,5\% dostosowaniem żywienia do ich indywidualnej diety. Inne preferencje oraz ich ważność związana z żywieniem przedstawiono na rysunku 5. 


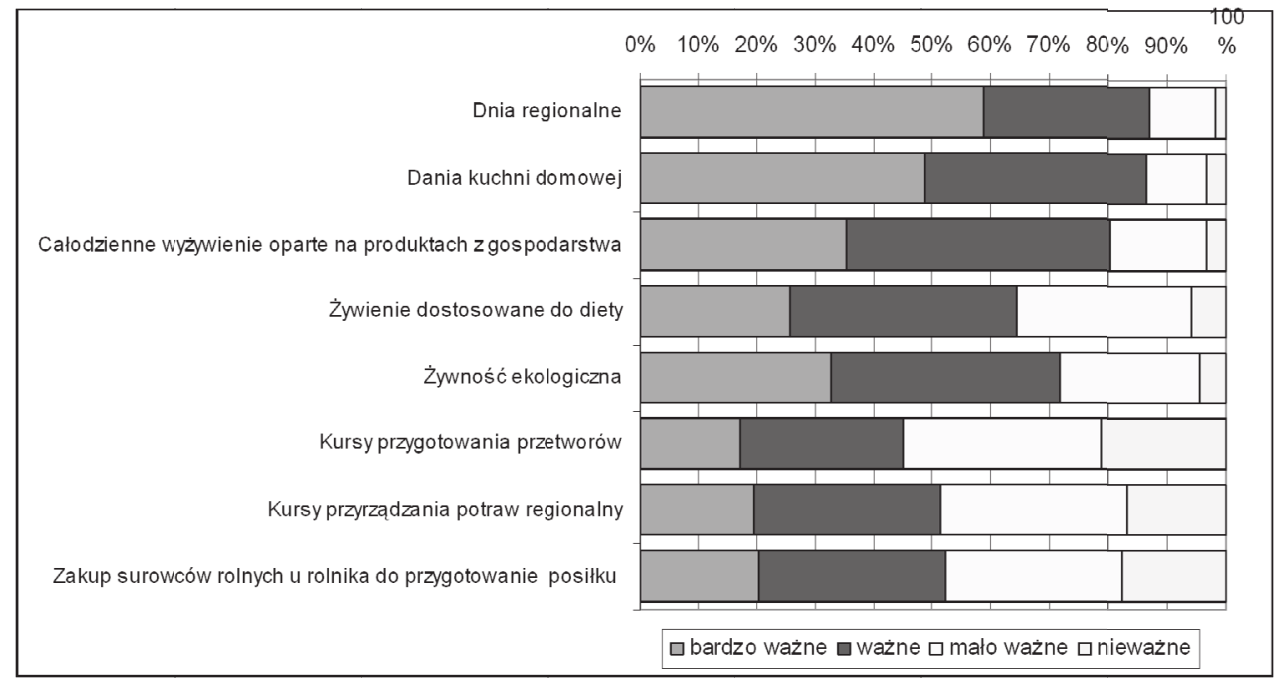

Rys. 5. Determinanty oraz ich ocena dotyczące bazy gastronomicznej gospodarstwa agroturystycznego

Fig. 5. Determinants and their assessment of the gastronomic base of the agritourism farm

Źródło: opracowanie własne.

Obszary wiejskie to także infrastruktura publiczna, walory przyrodnicze lub aktywny wypoczynek w najbliższym rejonie gospodarstwa. Z infrastruktury jako bardzo ważne i ważne wskazane zostały sklepy $(90,0 \%)$, zabytki $(78,0 \%)$. Respondenci zwracają też uwagę na zadbanie wsi $(78,4 \%)$, wytyczone szlaki turystyczne $(80,0 \%)$ czy sąsiedztwo lasu $(83,3 \%)$. Agroturystyka to też poszukiwanie ciszy i spokoju, $85,1 \%$ przywiązuje do tego dużą wagę. Większość osób chce odwiedzić gospodarstwa agroturystyczne nie dla zapoznania się z pracą na roli a dla bliskości obcowania z przyrodą. Wskazuje na to, iż tylko 35,6\% uważa możliwość poznania pracy rolnika za ważny aspekt a ponad dwukrotnie więcej osób chce korzystać z otaczającej przyrody. Piesze wycieczki dla 84,2\% są ważne a rowerowe dla $83,8 \%$, turystykę wodną w czasie wyjazdu chciałoby uprawiać $76,6 \%$. Poznanie lokalnej kultury i uczestnictwo w wydarzeniach tego typu ważne jest dla 73,3\%. $51,0 \%$ za ważne i bardzo ważne uznaje możliwość poznania rękodzieła i lokalnej kuchni. Strukturę ważności oraz inne determinanty przedstawiono na rysunku 6.

Analiza korelacji wykazała na poziomie istotności $\alpha=0,01$ wiele istotnych statystycznie zależności pomiędzy badaniami cechami. Z powodów technicznych, wielkości macierzy korelacji $75 \times 75$ nie zamieszczono jej, a dalej zostały przedstawione tylko najważniejsze według autorów istotne zależności. Cena usługi agroturystycznej została wskazana jako jedna z ważniejszych, cecha ta była skorelowana (wsp. korelacji 0,23 ) między innymi z wykształceniem. Wraz z wyższym poziomem wykształcenia malała ważność ceny jako determinanty. Cena była też skorelowana z miejscem zamieszkania $(0,33)$, wraz ze wzrostem miejscowości malała ważność ceny, podobna sytuacja to cena a zarobki (0,38), ważność ceny maleje wraz ze zwiększeniem zarobków. Miejsce zamieszkania były skorelowane $(0,19)$ z odległością gospodarstwa agroturystycznego. 


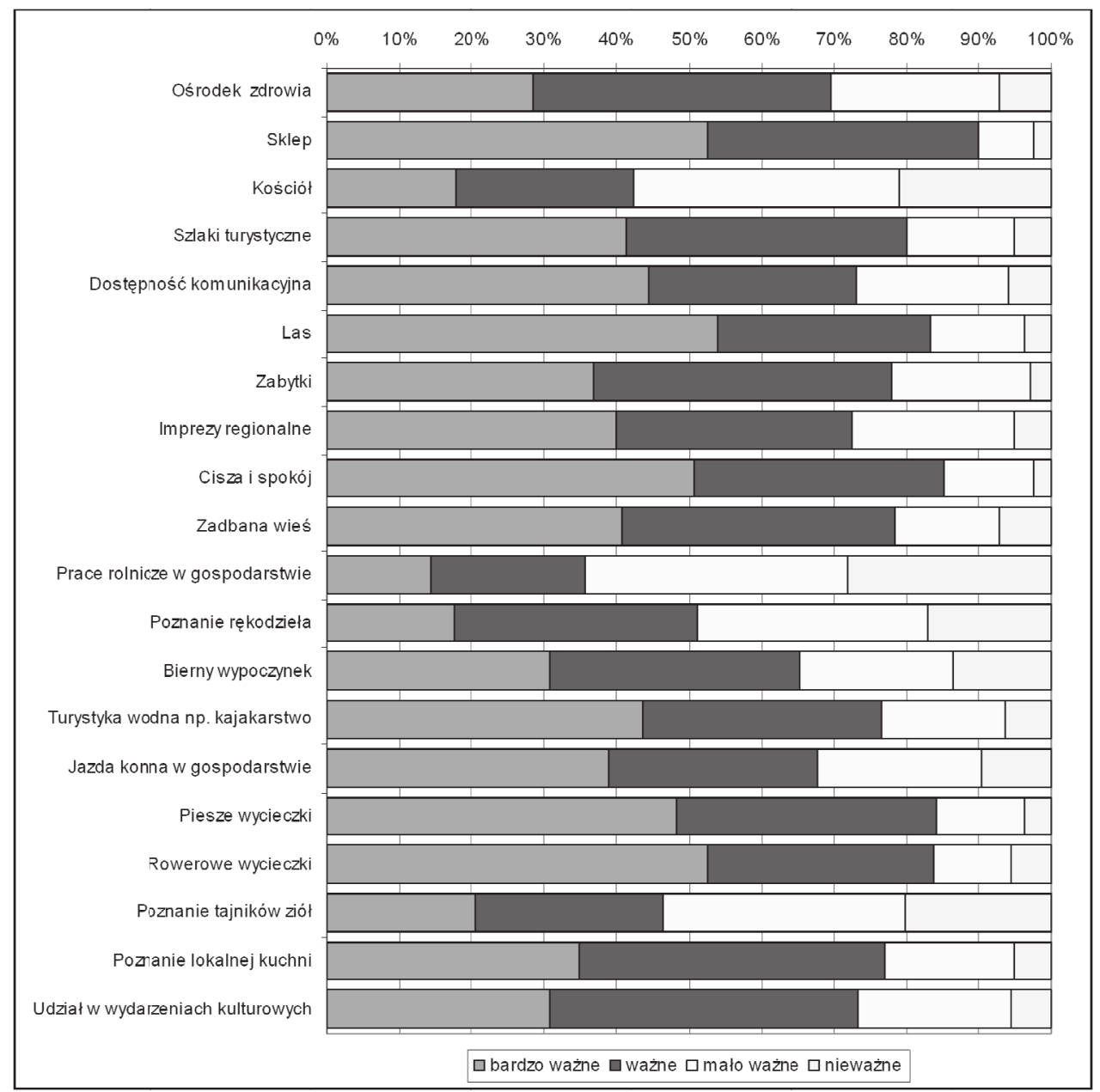

Rys. 6. Determinanty oraz ich ocena dotyczące okolicy gospodarstwa agroturystycznego oraz możliwości spędzania w nim wolnego czasu

Fig. 6. Determinants and their assessment of the area of the agritourism farm and the possibilities of spending free time in it

Źródło: opracowanie własne.

Jednym z ważniejszych demotywatorów były wysokie koszt usługi. Ważność wpływu ceny na decyzję wyboru gospodarstwa była istotnie skorelowana $\mathrm{z}$ miejscem zamieszkania $(0,31)$ i zarobkami $(0,18)$, wraz ze wzrostem wartości tych cech malała ważność wysokich kosztów jako demotywatora.

Z elementów oceny bazy noclegowej najwyżej oceniana jako ważna była czystość, nie stwierdzono żadnej zależności pomiędzy tą cechą a cechami metryczki co sugeruje, że bez względu na cechy kwaterobiorcy czystość jest zawsze najważniejsza.

Z wiekiem były skorelowane trzy cechy. Wraz ze wzrostem wieku badane osoby większą wagę przywiązywali: wygodzie spania $(-0,19)$ i wystroju regionalnemu wnętrz 
$(-0,20)$. Osoby wraz $\mathrm{z}$ wiekiem przywiązywały coraz mniejszą wagę dostępności do Internetu $(0,32)$. Ocena kwatery w kilku cechach była istotnie zależna od wieku. Wzrost wieku powodował zwiększenie ważności takich cech jak: obsługa $(-0,24)$, piękno ogrodu $(-0,23)$ czy możliwości wyżywienia $(-0,2)$. Osoby młodsze większą wagę przywiązywały do możliwości skorzystania $\mathrm{z}$ urządzeń rekreacyjnych $(0,20)$. Ocena położenia gospodarstwa a dokładniej infrastruktury $\mathrm{w}$ jej okolicy była uzależniona od wieku badanych (ze wzrostem wieku wzrastała ważność) w ocenie ważności występowania takich obiektów i cech jak: ośrodek zdrowia $(-0,23)$, kościół $(-0,26)$, zadbana wieś $(-0,17)$ oraz cisza i spokój $(-0,15)$. Istotny związek wystąił też pomiędzy determinantami spędzania wolnego czasu a wiekiem. W większości wraz ze wzrostem wieku malała ważność takich sposobów spędzania czasu jak: rowerowe wycieczki $(0,31)$, jazda konna w gospodarstwie $(0,31)$, turystyka wodna $(0,27)$ oraz piesze wycieczki $(0,17)$.

\section{Wnioski}

Agroturystyka jako bardzo szeroka i różnorodna forma spędzania czasu ma bardzo wiele ważnych determinant, które są brane pod uwagę. Z 71 zaproponowanych determinant wysoką ocenę (bardzo ważne i ważne) wskazaną przez ponad połowę respondentów uzyskało aż 62 cechy, a ocenę wysoką, wskazaną przez ponad 3/4 badanych otrzymało ponad połowa cech (37). Tak wysokie oceny ważności świadczą o dobrym doborze zaproponowanych determinant wyboru usług agroturystycznych, a ich duża liczba o złożoności zagadnienia oraz różnorodności form i sposobów wypoczynku w gospodarstwach agroturystycznych. Przeprowadzona analiza korelacji wykazała wiele istotnych związków pomiędzy cechami osobowymi lub pochodzeniowymi a preferencjami wyborów gospodarstw agroturystycznych. Najbardziej wpływową cechą na zmienność ważności postrzegania cech przy wyborze gospodarstw agroturystycznych był wiek respondentów. Wygoda i poziom wyposażenia był częściej wskazywany przez osoby starsze. Możliwości aktywnego wypoczynku natomiast bardzo ważne były dla osób młodszych. W analizach postawiono też tezę, iż sposób wyboru gospodarstwa agroturystycznego nie różni się ze względu na narodowość respondenta. Niestety z powodu zbyt dużej dysproporcji w poszczególnych trzech grupach narodowych badanych osób nie udało się takiej hipotezy odrzucić. Statystyki opisowe wskazywały podobieństwo pomiędzy Polakami a Białorusinami i Ukraińcami lecz braki w poszczególnych frakcjach cech metryczki nie pozwoliły na przeprowadzenie tych porównań szczegółowych. Niniejszym uogólnienia udowodnione statystycznie mogą być poczynanie tylko bez uwzględnienia narodowości.

\section{Literatura}

Balińska, A. (2009). Struktura popytu turystycznego i czynniki kształtujące ten popyt (na podstawie wyników badań empirycznych) (The Structure of Tourist Demand and Factors Moulding it (on the Basis of Empirical Research Results)). ZN SGGW Ekonomika i Organizacja Gospodarki Żywnościowej, 74, 137-147.

Balińska, A., Sieczko, A., Zawadka, J. (2014). Turystyka. Wybrane zagadnienia. (Tourism. Selected Issues). Wyd. Difin, Warszawa.

Dudzińska-Krawczyk, I. (2016). Agroturystyka zgodna z prawem (Agritourism is in accordance with the law). Wyd. Zachodniopomorski Ośrodek Doradztwa Rolniczego, Barzkowice 2016. 
Ustawa z dnia 2 lipca 2004 r. o swobodzie działalności gospodarczej (Act on Freedom of Business Activity). Dz.U. $2004 \mathrm{Nr} 173$ poz. 1807 z późn. zm.

Dziedzic, E., Skalska, T. (2012). Ekonomiczne uwarunkowania rozwoju usług turystycznych w Polsce (Economic conditions for the development of tourist services in Poland). Wyd. Stowarzyszenie na Rzecz Badania, rozwoju i Promocji Turystyki, Warszawa.

Gaworecki, W.W. (2003). Turystyka (Tourism). Wyd. PWE, Warszawa.

Sikora, J. (2012). Agroturystyka. Przedsiębiorczość na obszarach wiejskich (Agritourism. Entrepreneurship in rural areas). Wyd. C.H. Beck, Warszawa.

Wodejko, S. (1997). Ekonomiczne zagadnienia turystyki (Economic issues of tourism). Wyd. Prywatna Wyższa Szkoła Handlowa, Warszawa.

Santeramo, F.G., Barbieri C. (2017). On the demand for agritourism: a cursory review of methodologies and practice. Tourism Planning \& Development, 14, 139-148.

Zawadka, J. (2010). Ekonomiczne i społeczne determinanty rozwoju agroturystyki na Lubelszczyźnie (na przykładzie gmin wiejskich) (Economic and social determinants of the development of agritourism in the Lublin region (on the example of rural communes)) Wyd. SGGW, Warszawa.

Żelazna, K., Woźniczko, M. (2005). Uwarunkowania wyboru oferty turystyki wiejskiej w kontekście konkurencji na rynku usług turystycznych (Determinants of choosing the offer of rural tourism in the context of competition on the tourist services market). Turystyka i Rekreacja, 1, 87-93.

Do cytowania / For citation:

Sieczko A., Sieczko L. (2018). Determinanty popytu usług agroturystycznych. Problemy Rolnictwa Światowego, 18(2), 259-269; DOI: 10.22630/PRS.2018.18.2.53

Sieczko A., Sieczko L. (2018). Determinants of Demand for Agritourism Services (in Polish).

Problems of World Agriculture, 18(2), 259-269; DOI: 10.22630/PRS.2018.18.2.53 